\title{
Unconscious Structures in the Japanese Folk Tales Hebi No Yomeiri, Hato No Koukou, Tsuru No On'gaeshi, and Tanabata
}

\author{
Robi Wibowo \\ Universitas Gadjah Mada \\ Email: robiwibowo@yahoo.com
}

\begin{abstract}
This article analyzes four Japanese folk tales (myths) using the unconscious structures approach pioneered by Lévi-Strauss to uncover the connections between these myths and the unconscious structures of the society that holds them. The first step is to find the outer structures of the four analyzed myths and analyze them both synchronically and diachronically to find their component mythemes. The second step is to analyze and identify the inner structures of these mythemes. These inner structures can then be refined into a series of binary oppositions. Subsequently, the structures of these myths are connected to ethnographic data of the Japanese people, thus producing transformations which indicate the unconscious structures under investigatie. This analysis shows there are oppositional logics centered around the concept of duty, a fundamental part of Japanese morality - opposition between "willingness" and "reluctance" as well as between "gimu"and "giri". These oppositional logics are the unconscious structures of their reason for duty, rooted in the concept of "obeisance".
\end{abstract}

Keywords: Lévi-Strauss, unconscious structures, Japan, myth, morality

\section{INTRODUCTION}

The material objects of this research project are four folk tales (myths) from Japan: Hebi no Yomeiri, Hato no Koukou, Tsuru no On'gaeshi, and Tanabata. These folk tales were studied because they are assumed to include the hidden concepts and thoughts (the unconsciousness) of their society, which can thus be sought and ultimately discovered. This is in accordance with the theory of structural anthropology as presented in The Logic of Culture, which states that there is a certain "logic" or way of thinking maintained within a any individual culture (in Ahimsa-Putra, 2011: 20). It is this logic that is meant by the term "unconsciousness" above. Influenced by the theory of structural anthropology as mentioned above, this research project departs from the following assumption regarding these four Japanese folk tales - Folk tales are a part of culture. They contain within them a certain unconsciousness which takes the form of logic or a way of thinking. This research, therefore, attempts to discover the unconsciousness held in Japanese culture.

To discover the unconsciousness included in these four folk tales, these folk tales were analyzed using the structural approach pioneered by Claude Lévi-Strauss. Structuralism draws on a linguistic model, differentiating it from other approaches such as functionalism and Marxism. Heddy Ahimsa-Putra (2006: 66-71) identifies four core assumptions that differentiate LéviStraussian structuralism from other approaches. First, in structuralism there is an assumption 
that ceremonies, kinship and marriage systems, housing, fashion, and other cultural phenomena can all be considered "language" in a formal sense (Lane, 1970: 13-14; Ahimsa-Putra, 2006: 66). Second, structuralists hold that all normal humans have a genetically inherited ability to structure, formulate structures, or apply structures to observed phenomena. Everything we hear and see in our day-to-day lives, thus, is a manifestation of these structures. However, these manifestations are never complete; a structure can only be partially made manifest within a certain phenomenon; just as a single sentence can only manifest a portion of a language's structure (Ahimsa, 2006: 68). Third, following Ferdinand de Saussure's view that the meaning of a word is determined by its relationship with other words at a certain point in time (synchronic), structuralists consider the meaning of a cultural phenomenon to be determined by a certain phenomenon's synchronic relationship with other cultural phenomena. Fourth, the relationships contained within a structure can be simplified further to form sets of binary opposition, similar to how the words black (often related to darkness and evil) and white (often related to light, goodness, purity) are opposed to each other (Ahimsa-Putra, 2006: 60).

In Indonesia, the use of Lévi-Straussian structuralism to study literature and myths was introduced by Ahimsa-Putra (2001) and soon widely adopted by other academics to examine more complex social phenomena. For instance, structural analysis has been used to examine the structures of the Limas houses of Palembang (Purnama, 2000) and traditional houses in Sumbawa (Purwadi, 2002). Purnama explored the structure of the Limas houses of Palembang and related it to the structured way of thinking of the people of Palembang, whereas Purwadi focused more on revealing the structural principles behind the traditional Sumbanese houses in Umaluhu. As such, Purnama's analysis combined structural analysis with transformative analysis to better reveal the transformations which had occurred in the culture of Palembang. A structural approach was also used by Nasrullah (2008), who originates from the Bakumpai Dayak ethnic group in Sungai Barito, Kalimantan, to analyze the Bakumpai people's concept of space. The Bakumpai use the terms ngaju, ngawa, ngambu, and liwa to indicate directions; these concepts, aside from being closely related to space, are also strongly influenced by the rivers which play an important role in the Bakumpai people's lives.

These research projects indicate that structuralism, as a paradigm and approach, can be used to examine a variety of socio-cultural phenomena. Importantly, however, though all of the research projects mentioned above use different material objects, they focus on local cultures. As such, it is hoped that by researching a foreign culture, Japanese culture in this case, this article can expand the scope of and further develop structuralist research in Indonesia. Furthermore, by researching a foreign culture this article is hoped to build a greater intercultural understanding that may be useful for research into local cultures. In other words, this article is hoped to not only explain the logic and way of thinking of the Japanese people, but also to drive readers to reflect on the logic and way of thinking of the Indonesian people.

The structuralist method was used in this research project. In this method, data verification was conducted by preparing theoretical assumptions (Lane, 1970: 13). The most common manner of preparing these theoretical assumptions is by categorizing data (as explained below); this has been done for the current research project as well. The method used in this research project also proscribes a specific data-based standard operating and working procedure, albeit one based in theoretical assumptions.

Briefly, this research project employed the following method. First, the folk tales were read in their entirely. Through this reading, knowledge was obtained of the contents of the folk tales, the characters, the characters' actions, and the characters' experiences. Afterwards, the folk tales were divided into episodes which could serve as the basis for further research. In general, each episode consisted of a description of an action or event experienced by a character in the folk tale. As stated by Lévi-Strauss (1963: 210-211), these actions or events (more properly, these mythemes) can only be discovered at the sentence level. As such, this analysis initially focused on sentences that indicated an action or event experienced by a character from the folk tale. Unfortunately, this 
was not always appropriate, as occasionally a certain understanding or idea would be conveyed over several sentences. As such, the research approach was modified, allowing mythemes to be sought by focusing on successive sentences which presented a specific idea; this approach was more capable of indicating a certain "understanding" (Ahimsa-Putra, 2006: 206).

One mytheme's relation to another in a folk tale can give rise to another "understanding" altogether. This is what Ahimsa-Putra (2006: 206-207) refers to as an understanding which "seems to emerge from its new context". The "new" understanding in a certain folk tale can then be connected to a "new" understanding in another folk tale (for instance, Hebi no Yomeiri can be connected to Hato no Koukou, Hebi no Yomeiri can be connected to Tsuru no On'gaeshi, Hebi no Yomeiri can be connected to Tanabata). This also works to obtain an understanding within a different, oppositional, "context". These oppositions, on their own, do not have much meaning, but when connected to ethnographic data (particularly society's views of morality, ethnics, trust, etc.) they gain greater meaning. As such, this article also made use of appropriate ethnographic data regarding the Japanese people to discover the transformations of the oppositions contained within these folk tales.

\section{STRUCTURE OF HEBI NO YOMEIRI}

Once upon a time, a rich merchant saw a frog that was about to be eaten by a snake. Taking pity on the creature, the Merchant decided to help it. He told the Snake that, if it would release the Frog, the Snake could marry one of the Merchant's daughters (Purnomo, 2007: 123). After fulfilling its end of the agreement and releasing the Frog, the Snake demanded what had been promised to him. The Merchant, having made the promise when his only thought had been to save the Frog, found himself in a difficult position: how could he possibly allow one of his daughters to marry a snake? They would certainly object to the idea. After the Merchant's three daughters learned of their father's position, two refused. They were unwilling to marry the Snake. As such, the Merchant's anxiety grew. That was when the Merchant's youngest daughter gave him her answer: she would marry the Snake and thus help her father fulfill his promise. The Merchant was greatly relieved by his daughter's devotion (Purnomo, 2007: 124).

Though his promise to the Snake was almost fulfilled, the Merchant was still worried. How could he not be, with his youngest daughter about to marry the Snake? The Devoted Daughter was likewise anxious. Though her heart was pure and she was willing to sacrifice herself to help her father fulfill his promise, she was still swallowed by fear. Ultimately, however, the Devoted Daughter was able to avoid marriage to the Snake using a squash and a weaving needle given by her father (Purnomo, 2007: 123).

However, after killing the Snake, the Devoted Daughter was in grave peril as she was lost in the woods at night. In the middle of the forest she met an old woman, the human form of the Frog that the Merchant (the Devoted Daughter's father) saved. The Old Woman, to repay the kindness of the Merchant, helped the Devoted Daughter by offering her a place to sleep and recommending that she go to the house of a rich person in a nearby village. So that the Devoted Daughter would be protected from any ill-doers that she might pass, the Old Woman gave her some leather clothing (Purnomo, 2007: 125).

From this above tale, we can observe several inter-character relations: the Merchant, as he aided the Frog, is superior to the Frog; the Devoted Daughter always honors her parent, and is thus always inferior to him; the Snake is superior to the Merchant because he grants the request to release the Frog; the Frog is inferior to the Merchant because she is helped when the Snake tries to eat her. The inter-character relations and events above can be summarized as in Tables 1 and 2 below: 
Table 1

\begin{tabular}{llll}
\hline \multicolumn{1}{c}{ Character } & \multicolumn{1}{c}{ Actions } & \multicolumn{1}{c}{ Notes } \\
\hline 1 & The Merchant & Helps The Frog & Superior to The Frog \\
2 & The Devoted Daughter & Honors (parent) & Always inferior to (parent) \\
3 & The Snake & Grants the request of The Merchant & Superior to The Merchant \\
4 & The Frog (The Old Woman) & Helped by The Merchant, helps The Devoted & Inferior to The Merchant \\
& & Girl (returns the kindness of The Merchant) & \\
\hline
\end{tabular}

Table 2

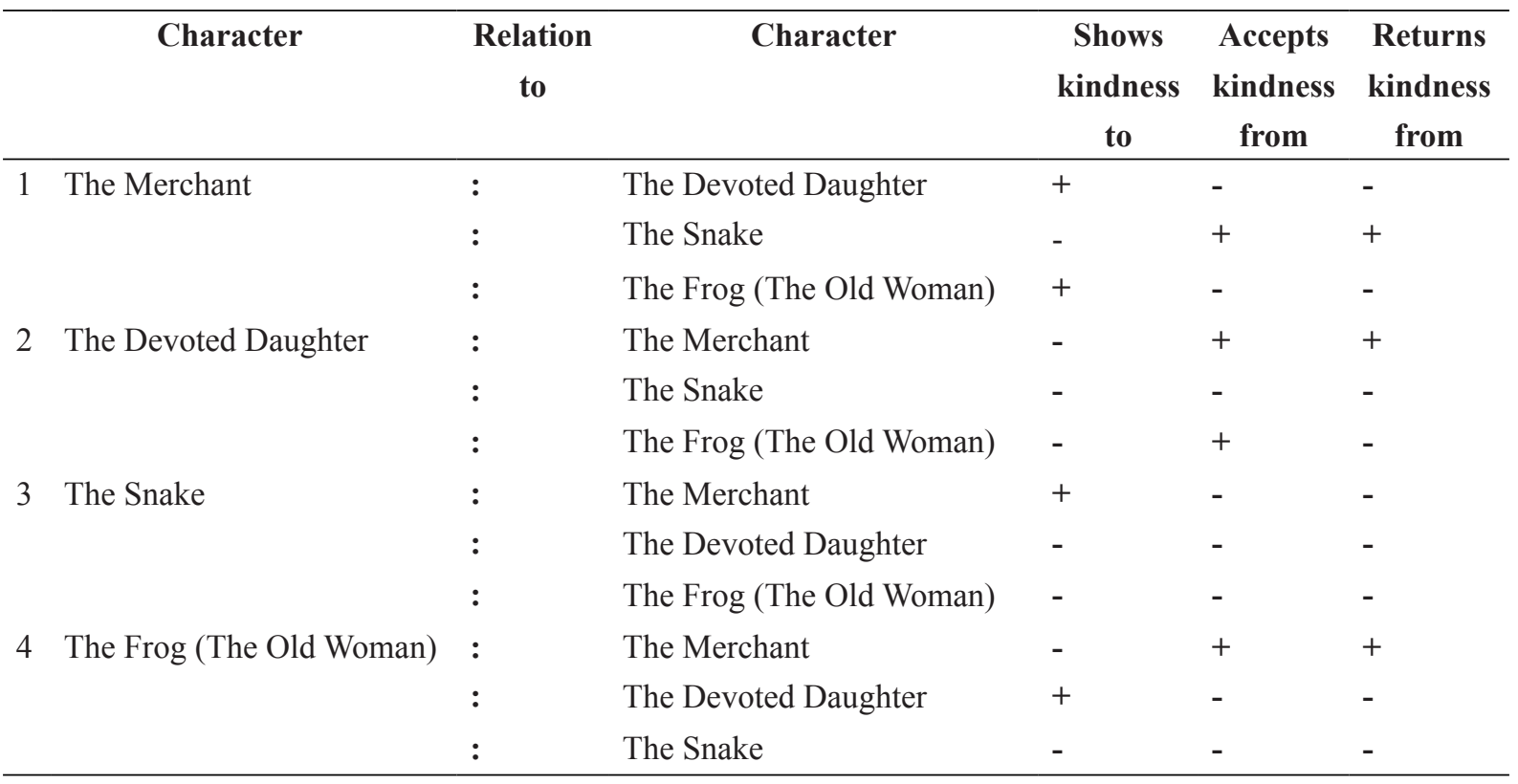

\section{STRUCTURE OF HATO NO KOUKOU}

Once upon a time, there was a young child named Hato who never obeyed his parents. Everything he did disappointed his parents greatly. Hato even ignored his ill father's last request, to be buried at the peak of a mountain when he died. As a parent, the Father hoped for a child who would obey and honor him - or at least repay the kindness that he had shown his child. However, the Father's hope to have a child who honored him - or at least repaid the kindness that he had shown - was never realized, even as he took last breath (Purnomo, 2007: 111)

One day, Hato began to reminisce on the kindness his father had shown him while he was still alive. The Father had, as Hato's parent, raised him and watched after him as he grew into adulthood. Hato felt that, as the Father's child, he could not simply forget the kindness he had received. As such, to repay his father's kindness, Hato decided to move his father's grave to the mountaintop, as he had requested. However, Hato was unable to realize this ambition for, while crossing the river, he fell and his father's bones were carried away by the current. Hato felt an overwhelming sadness and sense of regret. How could he not? Hato had intended to finally fulfill his father's request and thus honor him in a way that he had never done when his father was still alive. Hato felt as though his last chance to repay his father's kindness had vanished. Ultimately Hato transformed into a dove which always came to the river to cry over what he had done to his father (Purnomo, 2007: 112).

The relationship between the characters can be plotted as follows in Tables 3 and 4: 
Table 3

\begin{tabular}{llll}
\hline \multicolumn{1}{c}{ Character } & \multicolumn{2}{c}{ Actions } & \multicolumn{1}{c}{ Notes } \\
\hline 1 & The Father & Raises Hato & $\begin{array}{l}\text { Parent in parent-child relationship, should } \\
\text { thus be superior }\end{array}$ \\
& Hato (The Child) & Does not return parent's kindness & $\begin{array}{l}\text { Should be in an inferior position compared to } \\
\text { the Father, but Hato does not do as expected } \\
\end{array}$ \\
&
\end{tabular}

Table 4

\begin{tabular}{|c|c|c|c|c|c|c|}
\hline & Character & $\begin{array}{c}\text { Relation } \\
\text { to }\end{array}$ & Character & $\begin{array}{c}\text { Shows kindness } \\
\text { to }\end{array}$ & $\begin{array}{c}\text { Accepts } \\
\text { kindness from }\end{array}$ & $\begin{array}{c}\text { Returns } \\
\text { kindness from }\end{array}$ \\
\hline 1 & The Father & : & Hato (The Child) & + & - & Irrelevant \\
\hline 2 & Hato (The Child) & $:$ & The Father & Irrelevant & + & - \\
\hline
\end{tabular}

\section{STRUCTURE OF TSURU NO ON'GAESHI}

Once upon a time, a crane was caught in a hunter's trap. A young man soon released the Crane so that it could fly freely and escape the trap (Purnomo, 2007: 19-20). Afterwards, in a fierce snowstorm, the Youth found a young woman in front of his home who begged him to let her take shelter there. The Youth welcomed her into his home, lit a fire in the hearth, and made some tea to warm her; he knew that the Woman had surely been chilled by the blizzard. The Youth then said that the Woman was welcome to stay the night, if she did not mind his simple lodgings. He even offered her the opportunity to stay for several days, if she felt it necessary. The Woman felt grateful for the Youth's kindness (Purnomo, 2007: 19-20).

The Woman told her tale of woe. She no longer had a family and had to live by herself. As such, she begged the Youth to take her as his wife. She promised that, if she became his wife, she would work hard. Upon hearing this, the Youth agreed to take the Woman to be his wife (Purnomo, 2007: 20). The Woman, now the Wife, was truly grateful, a feeling she showed by preparing the Youth a delicious and full breakfast. She also cleaned and tidied the Youth's home (Purnomo, 2007: 20). The Wife also fulfilled her promise to work hard, weaving a beautiful brocade for him to sell in the town. What she did, thus, was to repay the kindness of the Youth who had helped her greatly (Purnomo, 2007: 20).

In short, the first story shows how the Youth helped the Crane when she in a difficult situation, caught in the hunter's trap. The second story also shows the Youth's kindness when he welcomes the Woman (who is, unbeknownst to him, actually the Crane in disguise) to come inside, warm herself, and stay at his home. In the third story as well, the Youth shows kindness by fulfilling the Woman's request to take her as his wife. From the three stories above, we can see a consistency in the mythemes regarding the relations between the two characters: the helper and the helped. The inter-character relations can be mapped as shown in Tables 5 and 6 below:

Table 5

\begin{tabular}{llll}
\hline Character & Actions & Notes \\
\hline 1 & Sang pemuda & Releases The Crane from a trap & The helper; shows kindness; superior \\
2 & The Crane (The Wife) & Returns the kindness of The Youth by The helped; owes kindness; returns \\
& & transforming in to a beautiful woman kindness, inferior \\
& and offering herself as his wife, so she \\
& may always serve The Youth \\
\hline
\end{tabular}


Table 6

\begin{tabular}{|c|c|c|c|c|c|c|}
\hline & Character & $\begin{array}{c}\text { Relation } \\
\text { to }\end{array}$ & Character & $\begin{array}{c}\text { Shows } \\
\text { kindness to }\end{array}$ & $\begin{array}{l}\text { Accepts } \\
\text { kindness } \\
\text { from }\end{array}$ & $\begin{array}{c}\text { Returns } \\
\text { kindness } \\
\text { from }\end{array}$ \\
\hline 1 & The Youth & $:$ & The Crane (The Wife) & + & + & - \\
\hline 2 & The Crane (The Wife) & $:$ & The Youth & + & + & + \\
\hline
\end{tabular}

\section{UNCONSCIOUS STRUCTURES}

From the inter-character relations and structures found in the above folk tales, we can see the transformations in the social reality of the society where these folk tales emerged. This reality is none other than the views taken by the Japanese people in their social lives. Descriptions about these views have been given by researchers such as Nitobe Izano (1969), Ruth Benedict (1982), Harumi Befu (1983), and Robert N. Bellah (1992). None of the above-mentioned researchers neglects to explore how the Japanese people give meaning to "duty" (known in Japanese as on, gimu, giri, and ninjou) and how it applies in their social lives. This, thus, emphasizes that the views of the Japanese people cannot be separated from how they give meaning to and implement various elements of "duty". As such, this research project's search for transformations in these folk tales also refers to this ethnographic data.

As stated above, in Hebi no Yomeiri the Merchant promises the Snake that the Snake may take one of the Merchant's daughters for his bride, so long the Snake releases the Frog he has captured. This promise is a debt which must be repaid. In other words, the Merchant's promise is an "obligation" that he must fulfill to maintain his relationships in society. The social construct demands that the Merchant follow the social code established within society, which includes fulfilling one's promises. This is what the Japanese people refer to as "obeisance" (Benedict, 1982: 140). Meanwhile, unlike "obeisance" which refers to one's social obligations, the greatest value in a family setting is "filial piety", which demands that a child must honor his or her parent(s) and do as his or her parent(s) desire.

As stated above, when the Merchant asks that one of his daughters marry the Snake, two immediately refuse. Only the youngest daughter is willing to marry the Snake and thus ensure that her father fulfills his obligations. Owing to her willingness to marry the Snake, she can be identified as a representation of a child who honors her parent(s), whereas her sisters can be identified as representations of children who do not honor their parent(s). At the end of the folk tale, it is told that the Devoted Daughter ultimately leads a happy life. What, then, about her sisters who were not as devoted to their father? This folk tale does not reveal their fate. As such it is necessary to identify another research object which can be used to discover the mytheme opposed to "a happy life". Only then can a new meaning be identified.

This oppositional mytheme can be found in the folk tale Hato no Koukou, which tells of the regret of a young boy named Hato who never honored his father when the latter was alive. One day, Hato remembered his late father's kindness and, knowing that he had never obeyed his father, decides to fulfill his father's last request and thus purge himself of his regret. Hato's intent to bury his father at the mountaintop was not realized, however, as he fell while crossing a river and his father's bones were swept away by the current. Hato felt an even greater sense of regret. He had only meant to fulfill his father's last request and thus honor him in a way that Hato had never done while his father was alive, and yet his last opportunity to repay his father's kindness had vanished. In the end, his regret was so great that Hato transformed into a dove. Since then, he has always returned to the river to cry over how he had treated his father.

Here, then, in these two folk tales the logic of the Japanese people is found, in the opposition between "obeying" and "not obeying", between "honoring" and "not honoring". This is what Lévi-Strauss terms the unconsciousness (AhimsaPutra, 2006: 75; Leach, 1974). The stories of Hebi no Yomeiri and Hato no Koukou indicate how the Japanese people convey their logic through 
the unconsciousness, particularly as it relates to the value of filial piety. Bellah (1992: 26) writes that this value, known as ko in Japan, is the most important of Japanese family values; it refers to how a child obeys his or her parent(s) requests and realizes his or her parent(s) desires.

The reason why the Japanese people consider filial piety of the utmost value for children in the context of their relationships with their parents can be found in the concept of on gaeshi, or the obligation for someone to repay the kindness that he or she has received. In relationships between parents and children, it is the children who have an on, or a debt of kindness, to repay their parents. The child's debt to his or her parents is without end and without limit. This, thus, is the basis for filial piety in Japanese society, for the honor and deference shown to parents, who occupy a strategic position of authority over their children. This on is of such importance that children will do anything they can to fulfill their duty and repay their debt. They attempt, as best as possible, to honor their parents, unlike in the West (such as in Germany) (contoh: Jerman) (Benedict, 1982: 108) because it is the parents who attempt to implant within them a sense of obligation and of filial piety. The Japanese people are well-aware of the importance of repaying the kindness of one's parents and of filial piety, such that a proverb has emerged: "Only once someone has become a father or mother does he or she know how great his or her debt is to his or her parents."

From the above discussion of these two folk tales, as well as the exploration of Japanese society's values, we can see an opposition of filial piety in the folk tales of Hebi no Yomeiri and Hato no Koukou. This opposition can be plotted as follows:

Hebi no Yomeiri : Youngest daughter 1: Loyal : Happy

Filial piety

Hato no Koukou : Dove : Not loyal : Regretful

The logic of the Japanese people in the folk tale Hebi no Yomeiri can be juxtaposed with the logic presented in another Japanese folk tale, namely Tsuru no On'gaeshi. The folk tale Hebi no Yomeiri presents the view of the Japanese people regarding a child's filial duty to repay his parent's kindness, whereas the folk tale Tsuru no On'gaeshi tellsof a crane who repays the kindness of a youth who has helped her greatly. In the latter tale, the Youth frees the Crane-who is actually a spiritual being - from a hunter's trap. She then transforms into a beautiful woman, finds the Youth, and asks to become his bride. Their marriage is intended to repay the kindness that the Youth had shown her; the Woman believes that, by becoming the Youth's wife and devoting her life to him, she can repay her debt to him.

Based on the above stories, it is apparent that two of the stories both deal with a character's repayment of kindness. The difference between the two stories is that one focuses on a child repaying a parent's kindness, whereas the other tells of a crane repaying a young man's kindness. A structural comparison of the two folk tales can be presented as follows:

\section{Hebi no Yomeiri: Tsuru no On'gaeshi : : \\ On to one's parents : $O n$ to one's peers}

The structures shown through the comparison of these two folk tales is reminiscent of the Japanese people's view that one is obligated to return kindness, or on. $O n$ is a term which refers to the psychological and social debt owed by someone after receiving gifts or kindness from others (Befu, 1983: 166). On can be understood either as duty or as generosity.

The Japanese language has many terms which refer to "duty" or "generosity". These words are not synonyms, but rather have specific denotations which cannot be translated into English. The word on, for instance, refers to all of a person's debts, from the greatest to the smallest, and can be roughly translated into English as "duty, loyalty, kindness, caring", but each of these translations change the fundamental meaning of the term (Benedict, 1982: 105).

One can be said to have on if one has received an award, gift, or kindness from someone. Family, as the main basis of the social structure, is where one first learns about one's debts and obligations and where these understandings are firmly implanted. Each family member is taught, over generations, the importance of one's on to one's 
parents, ancestors, and the State (Sugiyama, 1974: 195). In all of its uses, the term on refers to "a burden", "a debt", "something which must be borne by someone as best as possible". Having on, in Japanese culture, gives one a sense of being in a lower social position than the person to whom this on is owed. If one says "I have on to him," one means "I have the burden of duty to him."

There are numerous forms of on, including $k o$ on (on owed to the Emperor), oya on (on owed to one's parents), nushi no on (on owed to one's boss/ master), and on owed to others as part of daily life. The on holder has a "duty" to "repay" his or her on, his or her debt (Benedict, 1982: 105). Though this duty is not formally established through law, the sense of owing of owing on to someone and needing to repay it, is very strong; as such, repaying one's on, thoughnot a legal obligation, is nonetheless a moral one (Befu, 1983: 166). The repayment of one's on is referred to as gimu. For the Japanese people, working to repay one's debt (gimu) is a virtue (Benedict, 1982: 121).

The duty prescribed by one's on, which is both one-sided and without limit, is further strengthened by the Japanese people's systemic indoctrination in which all individuals are firmly reminded to always be aware of any and all things related to debt and gratitude. Violations of social norms related to these two duties bring with them considerable social sanctions. One who does not repay one's on is referred to as an on shirazu, a person incapable of repaying kindness. This term brings with it great social stigma, and is thus considered an insult to the person so referred. One recognized as an on shirazu will, as time passes, be ostracized by the community (Befu, 1983: 166).

The concept of on is hierarchal, meaning that the positon of the person owing on andperson owed on are not equal; the one owed on always occupies a higher position than one who owes on. One example of an ever-lasting hierarchal relationship is that between parents and children. Parents fulfill their children's needs for material, security, shelter, and love, and work to educate them. Children, meanwhile, receive and make use of all of their parents' kindness for duration the duration of their lives (Befu, 1983: 166).

Unlike the on owed to one's parents, on owed to one's peers is not without end. There is an implicit contract binding the person who owes on and the person who is owed on in a hierarchal relationship. This "contractual hierarchy" ends when the person who owes on has repaid his or her debtin the same amount as originally received.

To illustrate the repayment of one's on to a peer, Benedict (1982: 114) uses an example from Natsume Souseki's novel Botchan, which tells of the tensions between the novel's main character, Botchan, and a coworker, Yama Arashi. When Botchan is preparing to resolve his conflict with Yama Arashi, he remembers the on which he owes his coworker. The following day, Botchan throws a coin, valued at one and a half cents, onto Yama Arashi's desk. Only then, after he has repaid his on for a glass of iced water, can he resolve the dispute. This example shows the contractual and limited nature of on owed to one's peers: after the on has been repaid, one's "contract" is expired.

During the contract, bearing the burden of on is a service, albeit a conditional one: one is expected to not have any trouble repaying one's debt. This differs significantly with the on owed to one's parents, which is considered by the Japanese people to be unlimited, unconditional, and unwavering. Regarding this, Benedict (1982: 106) writes that, when one states that one loves one's parents and that one is unable to forget one's on to them, this is understood as a statement of devoted service to one's parents. This devoted service is endless and unconditional; for the Japanese people, this service cannot simply be understood as love for one's parents. It is more than that, a duty to repay the sacrifices undertaken by one's parents.

From the above ethnographic explanation, as well as the illustration from Natsume Souseki's novel, the juxtapositional meaning of Hebi no Yomeiri and Tsuru no On'gaeshi becomes clear. The folk tale Hebi no Yomeiri depicts a parentchild relationship in which kindness is given and received, whereas Tsuru no On'gaeshi depicts a relationship of peers. Both contain hierarchies, though these hierarchies have different characteristics. In Hebi no Yomeiri, the hierarchal relationship is endless and unconditional. In other words, the Japanese people believe that children will never be able to repay their on to their parents, and that the relationship between the 
two will always remain hierarchal. Children will always occupy a lower position than their parents. Meanwhile, hierarchal inter-peer relationships, such as that presented by Tsuru no On'gaeshi, are not without limits. The relationship between a person who owes on and who is owed on is, according to the Japanese people, a contractual and conditional one. As such, the structural meaning of these two folk tales can be represented as follows:

Hebi no Yomeiri: Tsuru no On'gaeshi : : On to one's parents : On to one's peers : :

\section{UNCONDITIONAL/WITHOUT A CONTRACT (ETERNAL) :CONDITIONAL, WITH A CONTRACT (TEMPORARY)}

Furthermore, as stated by Lévi-Strauss (citing de Saussure), the meaning of something is determined by its difference from other things; this applies to folk tales (myths) as well (AhimsaPutra, 2006: 50). The above analysis indicates that the meaning of the folk tale Hebi no Yomeiri can be found after it is juxtaposed with the folk tales Hato no Koukou and Tsuru no On'gaeshi. Based on de Saussure's assumption, the meaning of a folk tale can never be final, but rather depends on the folk tales to which it is compared. To test this assumption, this article presents juxtaposes another folk tale with Hebi no Yomeiri, namely Tanabata. Is it true that the presence of a different folk tale will lead to the emergence of another meaning of Hebi no Yomeiri?

In Tanabata, the Youth marries Tanabata, the daughter of the Sky Father (Purnomo, 2007: 170). Though they do not say it explicitly, the Sky Father and his wife do not approve of the marriage. If we examine the inter-character relations in the story, it is not difficult to understand that the Youth also realizes this. However, he never refuses to do what his parents-in-law demand. For the Youth, as a son-in-law, there is no reason to not do anything requested by his parents-in-law, even if it is difficult. This is his way of honoring his parentsin-law.

Meanwhile, Hebi no Yomeiri tells of a daughter's sincere obeisance of her birth father. The Devoted Daughter's sincere obeisance is intended as a way for her to honor her father, who raised her. As stated above, the folk tale
Hebi no Yomeiri tells of the youngest daughter of a merchant who, for her father's sake, is willing to marry a snake. Unlike her elder sisters, the Devoted Daughter believes that there is no reason to not do something if it will relieve a parent's burden (Purnomo, 2007: 124).

As with the Youth in the folk tale Tanabata, the Devoted Daughter in Hebi no Yomeiri has honored elder family members. The difference is that the elder family members in Tanabata are the parents of the Youth's wife (the Youth's parents-inlaw), whereas in Hebi no Yomeiri the elder family member is the Daughter's own father. As such, the relationship between the two folk tales can be plotted as follows:

\section{Tanabata: Hebi no Yomeiri::}

Honoring parents-in-law : honoring birth parents

The above depiction of the structured relationship of these two folk tales indicates the view of the Japanese people on "duty". Japanese society recognizes several categories of the showing kindness to others, including gimu, giri, and ninjou. Ninjou is defined by Cole (1973: 204) as an act of kindness done by an individual in response to his or her personal emotions, whereas gimu is understood as a "legal obligation". Gimu refers to the fulfillment of obligations which are limitless in size and quantity. Even the most slavish devotion to fulfilling one's gimu obligations would never be enough. Gimu is further divided into three sub-categories, namely one's duty to one's parents and ancestors $(\mathrm{ko})$, one's duty to the emperor, the law, and the State $(c h u)$, and one's duty to one's work (nimmu). Among the differences between giri and gimu is that the fulfillment of one's gimu obligations is always done with sincerity. Though gimu is understood as an "obligation", it is never defined through "reluctance" like giri. Giri, meanwhile, is the repayment of kindness in the same quantity and within a specific period of time (Nitobe, 1969: 106).

Giri refers to one's obligation to act in accordance with society's expectations in one's relations with other people. The word is used in reference to certain persons with an existing social relationship, and is thus better considered a specific norm than a general one. Harumi Befu (1983: 34) adds that giri is a norm which obliges one to honor 
and serve others reciprocally; people must help those who had helped them previously and show other forms of deference. This concept implies a moral movement which compels members of society to socially unite themselves through reciprocal activities or deeds, even when they are reluctant. Giri, thus, is an obligation that one fulfills with "a great reluctance". The term "a great reluctance" here indicates that the Japanese people act to fulfill their obligations or provide service within the ideological confines of giri tend to be influenced by external factors, namely others' judgments of them (Benedict, 1982: 140).

Giri covers all of one's obligations to the family of one's parents-in-law, whereas gimu is limited to one's birth family. This, thus, has led to the developments of terms such as giri father and giri mother for one's father- and mother-inlaw. Weddings in Japan are a contract between two families, and as such one must fulfill one's obligations to one's parents-in-law according to said contract for the duration of one's life; this is commonly referred to as "working for giri". In general, giri can be understood as the fulfillment of contractual obligations. This differs significantly from gimu, which is considered to be the fulfillment of one's obligation based on close relations established since birth.

As written above, the Japanese people consider their lives to consist of different circles of duty, including gimu (chu, ko, ninmu), giri, and ninjou. They do not judge people on their personality as a whole, but rather through statements such as "He does not know ko," or "He does not know giri." They identify the circles in which the judged person's actions to not fulfill their social contract. Though these are not circles of evil, it does not mean that the Japanese people do not know of ill deeds. They just do not view life as a stage on which the forces of good are at war with the forces of evil. Humans require balance between the different circles of duty, and all of them show goodness.
There are many cases in which Japanese people feel trapped by these circles of duty. Ninjou, for instance, may overshadow giri, such that someone is unable to repay his or her ko or chuu debts (Befu, 1983: 34; Benedict, 1982: 140). One may not be able to do "the right thing" "benar" (gi) because of one's giri. One may be forced by one's giri to act in a way that is detrimental to one's family. Rather than be ostracized and termed "a person who does not know giri", the Japanese people may ignore their own feelings or sense of justice. Statements such as "I did this for giri," or "If I had not done this, my giri would have suffered," are common. The opposition of doing "what is right" and fulfilling their giri traps them between two binding duties, both of which are considered "good" (Befu, 1983: 34-36).

From the above explanation of the Japanese people's understanding of "duty", we can conclude that the youth in Tanabata fulfills the requests of his father- and mother-in-law to fulfill his giri duties. Though he is actually unwilling to do these things, to ensure a harmonious relationship with his parents-in-law he feels "compelled" to take action. This, thus, is a duty based in reluctance, a duty which the Japanese people have implemented to protect their standing in the eyes of their society.

The daughter in Hebi no Yomeiri differs significantly. Based on the above ethnographic data, the Devoted Daughter does not act on a conscious sense of "reluctance". Rather, her decision to honor her father is based in a sense of "willingness". In her heart, as a child, she holds the teachings of "obeisance" and filial piety, which will stay with her for the rest of her life. She is not oriented towards the opinions or judgments of others. This, thus, is not what the Japanese people term "working for giri", but rather taking action to fulfill one's gimu. Gimu is thus based in a sense of willingness and not reluctance, a sense of individual desire and not the judgments of others/ society.

\begin{tabular}{|ll|} 
Heart : Mebi no Yomeiri: Gimu: Willingness: Individual : & $\begin{array}{l}\text { Not intended to receive the } \\
\text { judgment of others /masyarakat }\end{array}$ \\
Tanabata: Giri: Reluctance: Social : & $\begin{array}{l}\text { Intended to receive the judgment } \\
\text { of others /society }\end{array}$ \\
\hline
\end{tabular}




\section{CONCLUSION}

From this structural analysis of above four myths/folk tales, we can conclude that these myths have their own structures. Hebi no Yomeiri has the structure of a child returning a parent's kindness. Hato no Koukou has the structure of a child not returning a parent's kindness. Tsuru no On'gaeshi has the structure of a person returning the kindness of another person. Tanabata has the structure of a person following the orders of an in-law. After these structures are compared with ethnographic data on the source society, it is apparent that these four myths reflect the unconscious structures of the Japanese people. The unconscious structures discovered in this research are as follows: first, the structure of filial piety, between "honoring one's parents will lead to happiness" and "not honoring one's parents will lead to regret"; second, the oppositional structure of one's duty to one's parents and one's duty to others, with the former not being limited by contract (i.e. eternal) whereas the latter is the limited by contract (temporary); third, the different psychological structures of one showing "obeisance" to one's birth parents and of one showing "obeisance" to one's parents-in-law. For the Japanese people, showing "obeisance" to one's birth parents emerges from a sense of "heartfeltness" and is directed inwards, whereas showing "obeisance" to one's parents-in-law emerges from a sense of "reluctance" and is predominantly intended to receive positive judgment from others.

These unconscious structures are the Japanese people's view on the delineation of "duty". Through these myths, the Japanese people convey a series of oppositional logics regarding the position of duty in the context of "willingness" and "reluctance" as well as between "gimu" and "giri". These oppositional logics are the unconscious structures of their reason for duty, rooted in the concept of "obeisance".

\section{REFERENCES}

Ahimsa-Putra. (2001). Strukturalisme Lévi-Strauss: Mitos dan Karya Sastra. Yogyakarta: Galang Press.

(2006). Strukturalisme Lévi-Strauss: Mitos dan Karya Sastra. Yogyakarta: Kepel Press.
(2011). Wong Dulbur, Wong Legok, dan Wong Tiban: Struktur Nirsadar Novel "Jatisaba". Papers submitted in the Book Discussion : Novel Jatisaba, organized by the Department of Indonesian Letters Gadjah Mada University in Yogyakarta, March 9, 2011.

Befu, Haruni. (1983). Encyclopedia of Japan. Third edition. Japan: Kodansha.

Bellah, Robert N. (1992). Religi Tokugawa: Akar-Akar Budaya Jepang (Wardah Hafids and Wiladi Budiharga, Trans.). $1^{\text {st }}$ edn. Jakarta: Gramedia Pustaka Utama.

Benedict, Ruth. (1982). Pedang Samurai dan Bungan Seruni: Pola-pola Kebudayaan Jepang. (Pamuji, Trans.). Jakarta: Sinar Harapan.

Cole, Robert E. (1973). Japanese Blue Colar (The Changing Tradition). Barkeley: University of California Press.

Lane, M. (1970). Introduction to Structuralism (ed.). New York: Basic Books.

Leach, E.R. (1974). "Structuralisme in Social Anthropology" in D.Robey(ed.)Structuralisme: An Introduction.Oxford:Clarendon Press.

Levi-Strauss, Claude. (1963). Structural Anthropology. New York: Basic Books.

Matsuura, Kenji. (1994). Kamus Jepang-Indonesia. Jakarta: Gramedia Pustaka Utama.

Nasrullah. (2008). Ngaju, Ngawa, Ngambu, Liwa: Analisis Strukturalisme Levi-Strauss Terhadap Konsep Ruang Dalam Pemikiran Orang Dayak Bakumpai di Sungai Barito.(Master`s Thesis). Available from Gadjah Mada Universityt dissertation and theses database. UGM, Yogyakarta.

Nitobe, Inazo (1969). Bushido: The Soul of Japan. Tokyo: Charles E. Tuttle Co.

Purnama, Dadang Hikmah. (2000). Rumah Limas dan Struktur Pemikiran Orang Palembang. (Master`s Thesis). Available from Gadjah Mada Universityt dissertation and theses database. UGM, Yogyakarta.

Purnomo, Antonius R. Pujo. (2007). Tanabata: Kumpulan Cerita Rakyat Jepang Pilihan. Surabaya: Era Media

Purwadi. (2002). Prinsip-Prinsip Struktural dalam Rumah Tradisional Sumba di Umalulu. (Master`s Thesis). Available from Gadjah Mada Universityt dissertation and theses database. UGM,Yogyakarta. 
Robi Wibowo - Unconscious Structures in the Japanese Folk Tales

Sugiyama, Takie Lebra (Eds.). (1974). "Reciprocity and Reappraisal of the Japanese Concept of On"in Japanese Asymmetric Principle an Analytical Culture and Behavior, Sellected Readings. Amerika: University of Hawaii Press. 